\title{
Integration of a Computer Application in a First Year Accounting Curriculum: An Evaluation of Student Attitudes
}

\author{
Gregory Kenneth Laing \\ Faculty of Arts \& Business, University of the Sunshine Coast \\ Maroochydore, DC QLD, Australia \\ E-mail: glaing@usc.edu.au \\ Ronald William Perrin \\ School of Accounting \& Finance, Faculty of Commerce \\ University of Wollongong, Australia \\ E-mail: rperrin@uow.edu.au
}

Received: January 13, 2012

Accepted: February 8, 2012 Online Published: April 18, 2012

doi:10.5539/hes.v2n2p1

URL: http://dx.doi.org/10.5539/hes.v2n2p1

\begin{abstract}
This paper presents the findings of a field study conducted to ascertain the perceptions of first year accounting students concerning the integration of computer applications in the accounting curriculum. The results indicate that both student cohorts perceived the computer as a valuable educational tool. The use of computers to enhance the understanding/learning of tasks was favoured by $76.3 \%$ of semester 1 and $76.7 \%$ of semester 2 students Some differences between the student cohorts were considered to be due to the different teaching strategies. Interestingly, the most current experience, with computers, appeared to have the strongest influence on students' attitudes toward computer usage. Integration of the Academy Accounting System in the accounting curriculum contributed to the learning experience of the students.
\end{abstract}

Keywords: Accounting curriculum, Computer integration, First year accounting, Student attitudes

\section{Introduction}

The advent of affordable accounting software packages has made the task of recording transactions simple and easy for small and medium sized business entities across all industries regardless of their individual requirements. The software packages have also aided in reducing the burden on the accounting practitioners when faced with the daunting task of auditing the business records to determine the relevant tax liability or to satisfy compliance with legislation. Subsequently, a greater emphasis has been placed on the need for accounting graduates to have the requisite skills in the use of accounting software packages by prospective employers. Consequently, the integration of accounting software packages into the curriculum has grown as an important factor in preparing the accounting students for future employability.

Despite the importance of developing the requisite computer skills, a matter which had been raised in the Matthew's Committee in Australia (1990) and in the USA by Albrecht and Sack (2000), little attention has been given to addressing these issues or to examining a comprehensive approach to integration. Prior research has suggested that the adoption of computer technology into the accounting curriculum has suffered from a lack of attention to; pedagogical issues (Bromson, Kaidonis \& Poh 1994); overall integration (Steward \& Flanagan 1985); and the comprehension of underlying accounting concepts (Kent \& Linnegar 1988). The purpose of this study is to report on a process of developing a first year university level curriculum which addresses the three aspects that appear to have been neglected in the literature. Drawing on the education literature a model is developed that employs a holistic approach to the integration of computer applications into the curriculum.

\section{Literature Review}

Alternative approaches have been used to examine the concept of integration of computers in the accounting curriculum (Bhaskar, 1982; Doornekamp, 1993; Fetters, McKenzie \& Callaghan, 1986; Rivett, 1986). Armitage and Boritz (1986, 86) suggested integration should be aimed at developing computing skills across the range of accounting subjects, 
literally linking all subjects within an accounting degree. Ravel (1989) proposed a curriculum-wide approach to integrating computer usage in the accounting discipline and highlighted a wide spectrum of roles and constraints pertaining to users and teachers. The key components of the model were related to the hierarchy of learning (learning objectives) and the role of the computer (related to learning tasks). The concepts and constructs provided have a limited contribution to the process developed in this study. Hampton (1990) emphasised the use of computer technology, in the accounting curriculum, to disseminate knowledge; generate knowledge; and to manage information. Bromson, Kaidonis and Poh (1994) argued for a holistic approach in which teaching and learning should be linked to learning theory. They called for empirical research to examine the integration process using learning theory. Whilst the argument for an underpinning theoretical model is considered in this study the application of learning styles evaluation as suggested by Bromson et al (1994) was considered to be unnecessary for two reasons. Firstly, the testing of every student in each semester would be time consuming and less likely to provide a consistent approach for teaching since the curriculum would have to be designed with such a high level of flexibility to accommodate the different learning styles. Secondly, there is a body of research in the literature which points to the majority of accounting students as being from a particular category of learning style. While this may be considered as merely indicative of the expected student population it does provide the basis for the design of a curriculum that should suit the predominant learning style.

A key issue raised in the literature (Borthwick \& Clark 1987; Coy 1987; Collins 1983) is the need for integration of computers in the accounting curriculum to have a conceptual framework. A primary concern (Armitage \& Boritz 1986) is that the software should be relevant to the curriculum (ie topics being taught). Drawing on the work of Armitage and Boritz (1986) and Bromson et al (1994) the design of a curriculum should take into consideration: (1) the appropriateness of the software; (2) the means for teaching the software relevant to the accounting techniques; (3) the means to encourage students to build on their learning experience.

Helmi (1986) suggested that attention should be given to the importance of the issues form, content and substance when examining the level of integration of computer technology in the accounting education process. Table 1 provides an explanation and overview of the concepts. Helmi also considered the continued use of manual exercises, to impart the concepts and techniques of accounting, as essential to a holistic learning environment.

The integration of computer technology into the accounting education curriculum is not without its problems. An analysis of the literature by Togo and McNamee (1995) identified both the benefits and problems of computer usage in the teaching of accounting.

\subsection{Problems}

- $\quad$ Added time constraints:

o Learning software language

o Constructing accounting task with software

- Decreases available time for:

o Instruction/facilitation time

o Student learning

- Less problem practice by students

- Compounds learning difficulties

- Off the shelf software reduces motivation to understand concepts

- Inappropriate computer assignments

- Negative effect on student attitude

- Deemphasises learning accounting

- Requires higher level of analytical skills

2.2 Benefits

- Removes computational burden

- Improves analytical understanding of accounting

- Increases interest in accounting

- Aids learning process through:

o Creative thinking 
o Attention directing

o Productive thinking

- $\quad$ Supports illustrative teaching

- Facilitates transfer of learning:

o Comprehensive view of accounting

o Integrative nature of accounting

- Targets report formats and their data requirements

- Enhances understanding of risk analysis

- Allows for decision maker approach

In the current university environment most, if not all, of these benefits and problems still apply and would have to be weighed against each other. The models thus far have focused on the nuances required in the structure of a curriculum. What is missing is an emphasis on the teaching and support mechanisms that are relevant to the learning process.

The conceptual framework proposed in this study was further influenced by the theoretical constructs raised by Bromson et al (1994), Hampton (1990), Wheeler (1987), and Helmi (1986). This development process is congruent with the curriculum model proposed by Wheeler (1967), which emphasised the cyclical nature of the curriculum process and the interdependent nature of the curriculum elements. The framework with the inclusion of constraints and stakeholders, presented in Figure 1, is intended to provide a basis for understanding the implementation requirements when designing the accounting curriculum incorporating the use of computer software.

For the purpose of this curriculum integration the software package selected was Academy Accounting System (Laing \& Smith, 1996, 1993). This software was selected as it had been developed to meet the specific needs of a first year accounting curriculum at the university level. The software was came pack aged with a manual which provided instructions on the operations of the system as well as incorporating various exercises with revision questions. The student manual contained elementary exercises relating to the processing of financial transactions and in addition had a separate set of exercises that related to the use of spreadsheet software. The accounting software could be used in conjunction with any of the manual accounting practice sets that are readily available from the various publishers. In this regards the software was not restricted to use with any one text book or manual practice set.

Having determined that the Academy Accounting System software was consistent with the key curriculum constructs the next stage in the process was to address the alignment with the course content or topics (Wilcoxson, Wynder \& Laing, 2010). In this study the focus was on the First-year financial accounting course and subsequently the need to clarify that the alignment was appropriate. To achieve this the technique Quality Function Deployment (QFD) as proposed by Denton, Kleist and Surendra (2005) was selected. There are a number of reasons that this technique was relevant to the task at hand. First, the QFD technique is a method for assuring the quality of curriculum design meets the needs of all stakeholders, in particular the students and prospective employers. Second, the technique originated in Japan (Kogure \& Ako 1983) and was initially used to assess whether the design and manufacture of new products addressed all of the needs of the customer. Third, the technique has evolved and is used for, strategic planning (Maddux, Amos \& Wyskida 1991); project management (Hill \& Warfield 1991); and group decision support systems (Wolfe 1994). Fourth, the technique has been generally applied through the creation of graphical representation commonly referred to as the House of Quality (HoQ) and this was shown (Denton et al 2005) to have properties which were readily identifiable with curriculum issues in the educational setting. The HoQ for the integration of the academy accounting software in the first year accounting courses is provided in Figure 2 below.

\section{Method}

This study relates to the use of the academy accounting system in two separate semesters. The number of first year students in the semesters varied. In semester one there was a cohort of 284 and in semester two 296 first year students. The questionnaire instrument was structured to provide a response from the students concerning three aspects of computer integration in the accounting curriculum. Students were asked for their opinion concerning three areas: (1) the linkage between software and course content/topics, (2) the level of continuity between accounting software and manual bookkeeping, and (3) the usefulness of the software for solving problems and for learning. In addition students were provided with the opportunity to comment on their answers. Students were advised that only the use of computer technology as it related to the course (i.e. stated in the course outline) was relevant for the purpose of completing the questionnaire. The questionnaire consisted of a number of questions, in some instances students were asked to simply provide a yes or no answer whilst to others they were asked to provide a response on a scale of 1 to 7 . The rating scale was arranged with the low numbers representing "strongly disagree" and the high numbers "strongly agree". The Likert 
scale was structured to provide a measure of the student's attitude and/or perception in regards to computer applications in the educational process. The structure was adapted from the format used by Porter (1962) to measure the perceived deficiencies in need fulfilment of managers and also draws on the works of Kay (1993), Francis (1993), Hassan and Shrigely (1984), and Schibeci (1982) which specifically relate to the design of instruments to measure student attitudes. The questions asked were adapted from the studies of Hampton (1985) and Armitage and Boritz (1986). These issues focused on the use and application of computer software. Generic terms were used to refer to software in an attempt to alleviate any instances where students may have used different software or more than one package e.g. Lotus 123 or MS Excel.

To measure student attitude the definition of attitude by Statt (1981) was adopted. Basically, Statt (1981) defined attitude as "A stable, long lasting, learned predisposition to respond to certain things in a certain way. The concept has a cognitive (feeling) aspect, and a connotative (action) aspect.” Flavell and Wellman (1977) found that as individuals mature they become more adept at identifyin their own abilities and interpreting their experiences. Leite (1994) found that students had a positive attitude toward computer usage with no significant differences between male and female students or even students taking or not taking a computer related course. Brace and Roberts reported finding that students had developed an improved understanding of abstract concepts as a result of the incorporation of computer usage in the learning process. Haladyna and Shaughnessy (1982) examined student attitudes toward science curriculum in particular the relationship between student, lecturer (teacher), and computer usage and provided some guidance on the approach to the instrument design. Koohang (1989) provided details of four types of attitude toward computers specifically, the concepts of anxiety, confidence, liking, and perception of usefulness. These were particularly useful in the design of the instrument used in this study.

As an attitude is deemed to be attributable to some learned predisposition it is inferred that the mentoring program has contributed to the development of the attitude expressed by students. This is consistent with the position of Skinner (1957) that an individual's response tendencies are shaped by experiences which he referred to as operant conditioning. This is also consistent with the notion of reciprocal determinism which Bandura $(1977,1986)$ had argued was an extention of Skinner's theory. The idea in reciprocal determinism being that there is an interaction that takes place as a form of learned behaviour emanating from experiential learning.

\section{Results}

The educational value of computer usage from the perspective of the students provided some interesting results. Table 2 shows that the majority of students (76.3\% semester 1 and $76.7 \%$ semester 2 perceived the use of computer software as enhancing their understanding and learning of the accounting tasks. This result is consistent with the findings reported by Brace and Roberts (1996).

This perception, that the computer software usage was useful, is further supported by $68.4 \%$ of semester 1 and $86.7 \%$ of semester 2 students advocating that computer software was valuable in performing manual accounting tasks. This however must be weighed against the responses to the question of whether the use of computer software should be increased, with only $47.4 \%$ of semester 1 and $43.5 \%$ of semester 2 students supporting an increase. The comments from the students, who were not in favour of an increase, indicated a perception that the amount of computer software usage was adequate and required no further increase.

The responses to the questions shown in Table 3 indicate that students perceived a high level of consistency between the tasks undertaken using the computer software and the course curriculum. In relying on these results caution should be exercised as the results may be biased by the students being influenced by their most recent experiences (Flavell \& Wellman, 1977).

The final analysis is of the students responses to the question regarding the usefulness of the different computer software for problem solving or learning. Table 4 presents the mean responses to the three basic types of software that students had used during the relevant semester. It is not surprising that the use of a spreadsheet was rated more highly as being useful for problem solving or learning than that of the accounting software. This is because the spreadsheet allowed the students greater opportunity to come to grips with the formulation and eventual solution to a particular task unlike the accounting software which simply required the student to identify the correct transaction details before recording a transaction.

\section{Conclusion}

The results indicate that both sets of students in the different semesters perceived that the integration of the use of computer software contributed to their learning and assisted them in the completion of the tasks associated with the curriculum. While some differences in opinion are evident the overall response to the integration was favourable. The difference between semesters is likely to be due to the influence of the academic staff being more familiar with the 
software and its application. That is the teaching by the academic staff may have adapted to the inclusion of the computer usage and thus would explain the higher responses in some areas by the semester 2 students.

Both student cohorts identified that computer software was valuable to their learning process and had assisted in regards to problem solving. It appears form the responses that the integration was successful in achieving the desired alignment between the curriculum and the usage of the computer software for the accounting tasks.

The conceptual framework presented in Figure 1 has been shown to offer some potential benefits for evaluation of the curriculum design and future research may provide more rigorous testing of the frame work at different stages of development. The house of quality technique has also shown potential for use in determining the relevance of curriculum at the topic level on a week by week basis and may be an approach that future researchers may find useful for areas such as criterion assessment.

\section{References}

Albrecht, W., \& Sack, R. (2000). Accounting Education: Charting the Course through a Perilous Future, American Accounting Association, Accounting Education Series, 16: Sarasota FL.

Armitage, H.M., \& Boritz, J.E. (1986). Integrating Computers into the Accounting Curriculum, Issues in Accounting Education, (Spring) 1(1):86-101.

Bandura, A. (1977). Social Learning Theory, Prentice-Hall: Englewood Cliffs, NJ.

Bandura, A. (1986). Social Foundations of Thought and Action: A Social-cognitive Theory, Prentice-Hall: Englewood Cliffs, NJ.

Bhaskar, K.N. (1982). Use of Computers in Accounting Courses, Accounting and Business Research (Winter), 13(49): 3-10.

Borthwick, A.F., \& Clark, R.L. (1987). Research on Computing in Accounting Education: Opportunities and Impediments, Issues in Accounting Education, 2(Fall):173-192.

Brace, S.B., \& Roberts, G. (1996). Supporting Faculty's Development and Use of Instructional Technology, in Procedings of the Mid-South Instructional Technology Conference (1st, Murfreesboro, Tennessee, March 31 - April 2, 1996).

Bromson, G., Kaidonis, M.A., \& Poh, P. (1994). Accounting information systems and learning theory: An integrated approach to teaching, Accounting Education, 3(2):101-114. http://dx.doi.org/10.1080/09639289400000008

Collins, R. (1983). Computers and Accounting Courses: A Comment, Accounting and Business Research, (Autumn) 13(52): 312-314.

Coy, D.V. (1987). Computers in Accounting Education: A Literature Review, Massey University Department of Accounting and Finance, Discussion Paper \#63.

Denton, J., Kleist, V., \& Surendra, N. (2005). Curriculum and Course Design: A New Approach Using Quality Function Deployment, Journal of Education for Business, 81(2), 111-117. http://dx.doi.org/10.3200/JOEB.81.2.111-118

Doornekamp, B.G. (1993). Students Valuation of the Use of Computers in Education, Computers Education, 21 (1/2):103-113. http://dx.doi.org/10.1016/0360-1315(93)90053-L

Fetters, M., McKenzie, J., \& Callaghan, D. (1986). Does the Computer Hinder Accounting Education: An Analysis of Some Empirical Data, Issues in Accounting Education, (Spring) 1(1): 76-85.

Flavell, J.H., \& Wellman, H.M. (1977). Metamemory, in R.V. Kail and J.W. Hagen (Eds) Perspectives on the Development of Memory and Cognition, Hillsdale, NJ Erlbaum.

Francis, L.J. (1993). Measuring Attitude Toward Computers Among Undergraduate College Students: The Affective Domain, Computers Education, 20(3):251-255. http://dx.doi.org/10.1016/0360-1315(93)90024-D

Haladyna, T., \& Shaughnessy, J. (1982). Attitudes toward Science: A Qualitative Synthesis, Science Education, 66(4):547-563. http://dx.doi.org/10.1002/sce.3730660406

Hampton, G. (1985). Some thoughts on the Computer and Accounting Education, Accounting Forum, 8(2), 17-27.

Hampton, G. (1990). The Use of the Computer in Accounting Education: A Taxonomy, Accounting Forum, 14(2): 80-96.

Hassan, A. M. A., \& Shrigley, R.L. (1984). Designing a Likert Scale to Measure Chemistry Attitudes, School Science and Mathematics, 84(8): 659-669. http://dx.doi.org/10.1111/j.1949-8594.1984.tb09581.x

Helmi, M.A. (1986). Integrating the Microcomputer into Accounting Education Approaches and Pitfalls, Issues in Accounting Education, (Spring)1(1): 102-111. 
Hill, J., \& Warfield, J. (1972). Unified program planning, IEEE Transactions on Systems, Man, and Cybernetics, 2(5), 610-621. http://dx.doi.org/10.1109/TSMC.1972.4309189

Kay, R. H. (1993). An Exploration of Theoretical and Practical Foundations for Assessing Attitudes Toward Computers: The Computer Attitude Measure, Computers in Human Behaviour, 9(4): 371-386. http://dx.doi.org/10.1016/0747-5632(93)90029-R

Kent, P. F., \& Linnegar, G. H. (1988). Integrating Computers into Accounting Education - A survey of Australian Universities and Colleges, Accounting and Finance, 2: 81-91. http://dx.doi.org/10.1111/j.1467-629X.1988.tb00149.x

Koohang, A.A. (1989). A Study of Attitudes Toward Computers: Anxiety, Confidence, Liking, and Perception of Usefulness, Journal of Research on Computing in Education, 22(2): 137-150.

Laing, G.K., \& Smith T.R. (1993). Academy Accounting System - Student’s Manual, Harcourt Brace Jovanovich: Sydney. Laing, G.K., \& Smith T.R. (1996). Academy Accounting System $2^{\text {nd }}$ Edn., Harcourt Brace: Sydney.

Leite, P.T. (1994). College Students’ Attitudes Toward Computers, Research Paper, ERIC No: ED371684.

Maddux, G., Amos, R., \& Wyskida, A. (1991). Organizations can apply quality function deployment as strategic planning tool, Industrial Engineering, 23(9), 33-37.

Porter, L.W. (1962). Job Attitudes in Management, Journal of Applied Psychology, 46(6): 375-384. http://dx.doi.org/10.1037/h0047808

Raval, V. (1989). A Curriculum-wide Approach to Integration of Computer in Accounting Education, Journal of Information Systems, 3(2): 132-144.

Rivett, D.W. (1986). Integration of Microcomputers into the Financial Accounting Curriculum, Accounting Forum 13:63-64.

Schibeci, R.A. (1982). Measuring Student Attitudes: Semantic Differential or Likert Instruments?, Science Education, 66(4):565-570. http://dx.doi.org/10.1002/sce.3730660407

Skinner, B. F. (1957). Verbal Behavior, Appleton-Century-Crofts: New York. http://dx.doi.org/10.1037/11256-000

Statt, D. (1981). A Dictionary of Human Behaviour, Harper \& Row, Publishers, London.

Steward, B., \& Flanagan, J. (1985). A Framework for Evaluating the Integration of Computers within Accounting Education, Annual Conference, Accounting Association of Australia and New Zealand.

Togo, D., \& McNamee, A. (1995). Computer Integration into the Accounting Curriculum: Learnign Benefits, Problems, and Guidelines, Journal of Accounting Education, 13(2): 149-158. http://dx.doi.org/10.1016/0748-5751(95)00004-6

Willcoxson, L., Wynder, M., \& Laing, G. (2010). A Whole-of-program Approach to the Development of Generic and Professional Skills in a University Accounting Program, Accounting Education, Accounting Education: an international journal, 19(1-2), 65-91. http://dx.doi.org/10.1080/09639280902886082

Wolf, M. (1994). Development of the city of quality: A hypertext-based group decision support system for quality function deployment. Decision Support Systems, 11(3), 299-318. http://dx.doi.org/10.1016/0167-9236(94)90078-7 
Table 1. Overview of the Concepts of Form, Content and Substance

\begin{tabular}{|l|l|l|}
\hline Form & Content & Substance \\
\hline $\begin{array}{l}\text { Special applications that address } \\
\text { each course individually. }\end{array}$ & $\begin{array}{l}\text { The use of computer technology to } \\
\text { assist with instructions and as a tool } \\
\text { to solve problems. }\end{array}$ & $\begin{array}{l}\text { Examination of dedicated software } \\
\text { and techniques of program } \\
\text { development and systems. Tasks } \\
\text { may be conducted simultaneously on } \\
\text { a manual and computer level. }\end{array}$ \\
\hline
\end{tabular}

Table 2. Educational Value of Computer Usage

\begin{tabular}{|l|l|l|}
\hline Question & $\begin{array}{l}\text { Semester 1 [n = 76] } \\
\text { Yes responses }\end{array}$ & $\begin{array}{l}\text { Semester 2 [n= 62] } \\
\text { Yes responses }\end{array}$ \\
\hline $\begin{array}{l}\text { Did the use of the computer software to perform the } \\
\text { accounting task enhance you understanding or learning? }\end{array}$ & 58 76.3\% & $46.7 \%$ \\
\hline $\begin{array}{l}\text { Did the academy accounting software assist you to } \\
\text { understand the manual accounting tasks? }\end{array}$ & $5268.4 \%$ & $28.7 \%$ \\
\hline $\begin{array}{l}\text { Would you recommend an increase in the use of } \\
\text { computer software in first year accounting? }\end{array}$ & $3647.4 \%$ & $43.5 \%$ \\
\hline
\end{tabular}

Table 3. Usefulness of Academy Accounting System

\begin{tabular}{|l|l|l|}
\hline $\begin{array}{l}\text { Question - How useful was the academy accounting } \\
\text { system for learning to: }\end{array}$ & $\begin{array}{l}\text { Semester 1 } \\
\text { Mean of responses }\end{array}$ & $\begin{array}{l}\text { Semester } \mathbf{2} \\
\text { Mean of responses }\end{array}$ \\
\hline Set up General Ledger Chart of Accounts & 6.2 & 6.4 \\
\hline Record Opening Entries & 5.9 & 6.1 \\
\hline Record Balance day adjustments & 5.9 & 6.1 \\
\hline Record accounts receivable transactions & 5.9 & 6.3 \\
\hline Record accounts receivable transactions & 6.1 & 6.3 \\
\hline Record accounts payable transactions & 6.2 & 6.4 \\
\hline
\end{tabular}

Table 4. Comparison of Computer Software Usage

\begin{tabular}{|l|l|l|}
\hline Software & $\begin{array}{l}\text { Semester 1 } \\
\text { Mean of 1-7 responses }\end{array}$ & $\begin{array}{l}\text { Semester 2 } \\
\text { Mean of 1 - 7 responses }\end{array}$ \\
\hline Academy Accounting System (software) & 5.6 & 6.1 \\
\hline Spreadsheet (software) & 6.5 & 6.7 \\
\hline Wordprocessing (software) & 6.1 & 6.2 \\
\hline
\end{tabular}

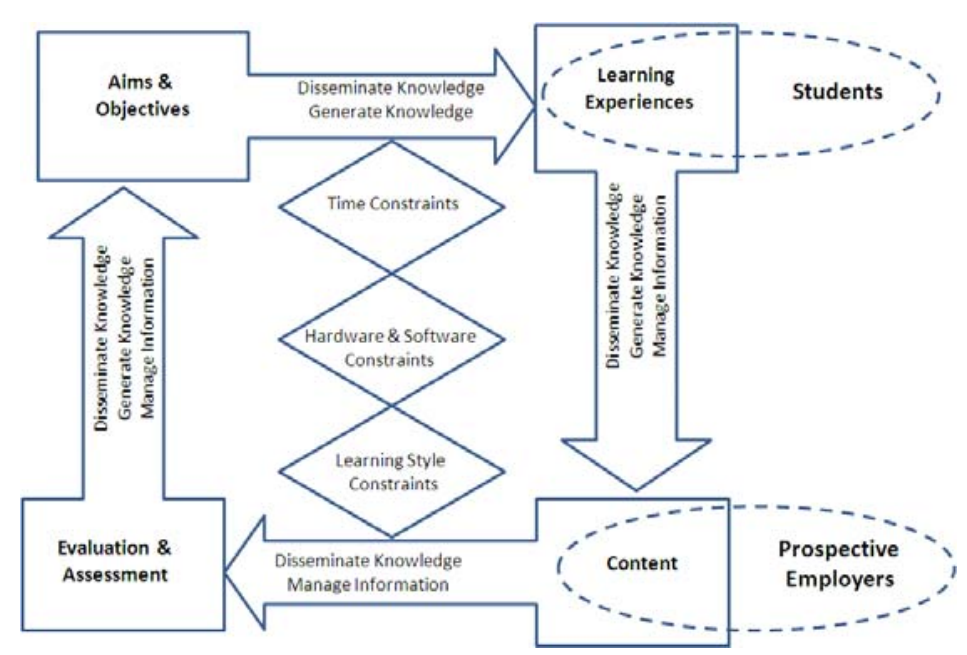

Figure 1. Curriculum Conceptual Framework 
House of Quality

Project: Curriculum Computer Integration

Academy Accounting System
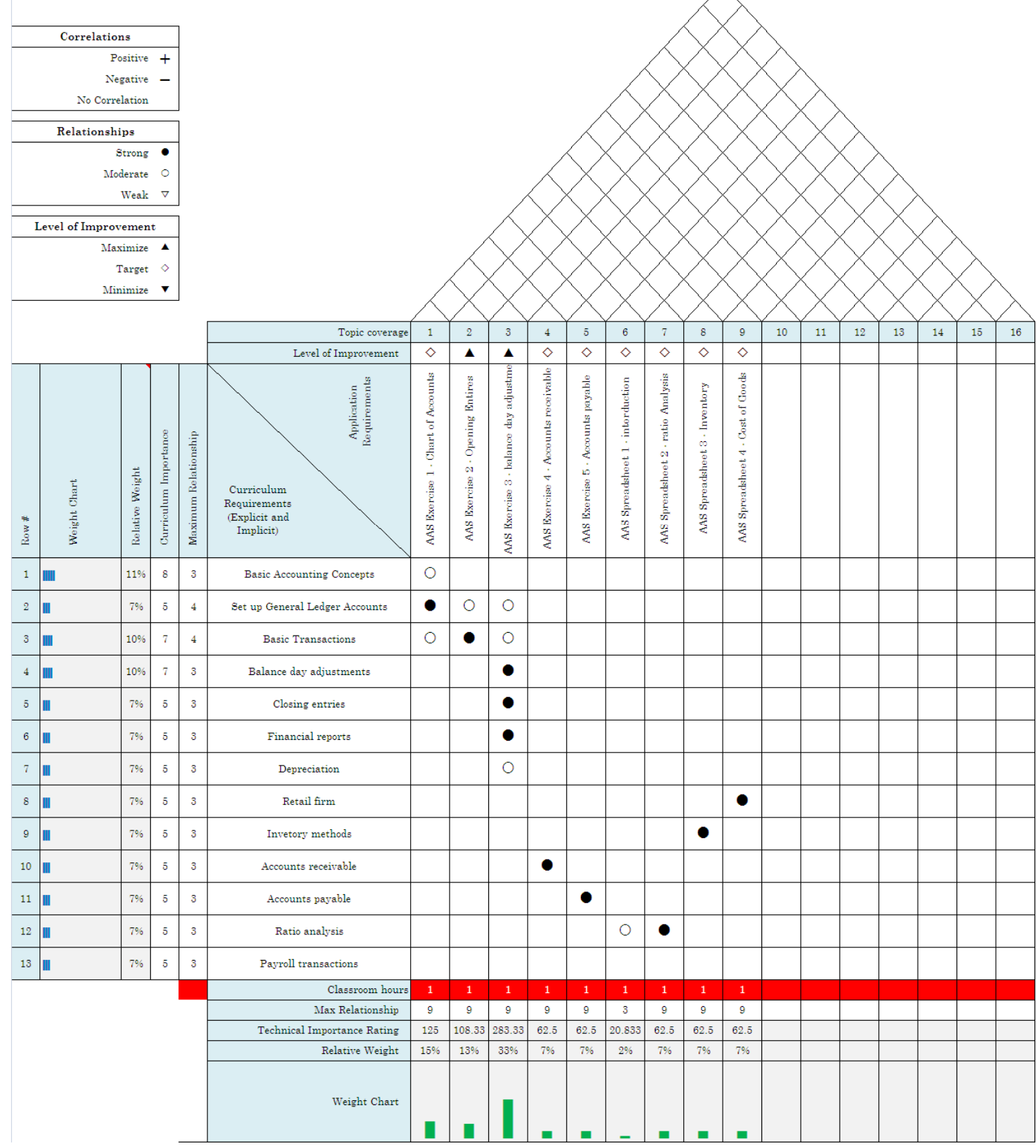

Figure 2. HoQ for the Integration of the computer software into the curriculum 